\title{
Ladislaus Jagiello in Modern Polish Culture
}

\section{Banaszkiewicz}

For citation: Banaszkiewicz M. Ladislaus Jagiello in Modern Polish Culture. Vestnik of Saint Petersburg University. History, 2021, vol. 66, issue 3, pp. 828-844. https://doi.org/10.21638/11701/spbu02.2021.309

This article deals with Polish representations of Władysław II Jagiełło, Grand Duke of Lithuania, ruler of the Crown of the Polish Kingdom, founder of the Jagiellonian dynasty. Research on representations of the past has become one of the main fields of memory studies in recent years. They allow us to look at historical events and their emblematic protagonists through the prism of their successive emanations. The kaleidoscope of images of the past reflects changes in social awareness and collective memory of a given political community. Jagiełło and the Battle of Grunwald (1410), which is inseparably associated with his reign, offer a model case in point. Among the numerous representations of Jagiełło, those created in the nineteenth century have made a lasting impression. At first, they took the form of literary works and paintings, and only later did they appear in political journalism and historiography. With time, they transmogrified into grass-roots commemorative initiatives, the most spectacular manifestation of which was the jubilee of the 500th anniversary of the Battle of Grunwald, celebrated in Kraków in 1910. The works of Józef Ignacy Kraszewski, Henryk Sienkiewicz and Jan Matejko fulfilled their role and became part of the canon, on which the Polish imagination depended from then on, regardless of the changing political configurations. In this way, Jagiełło became one of the most important figures in the pantheon of rulers, while the distant historical experience of the Polish-Lithuanian Commonwealth was permanently grafted onto and modelled the Polish political imagination. This observation is also confirmed by his twentieth-century portrayals in Polish films and historical series.

Keywords: Ladislaus II of Poland, Battle of Grunwald, Polish-Lithuanian Commonwealth, Teutonic Order, representations.

Mikolaj Banaszkiewicz - PhD, Research Associate, The Jagiellonian University, 24, Gołębia, Cracow, 31-007, Poland; Visiting Researcher, St. Petersburg State University, 7-9, Universitetskaya nab., St. Petersburg, 199034, Russian Federation; mikolaj.banaszkiewicz@gmail.com

Миколай Банашкевич - PhD, науч. сотр., Ягеллонский университет, Польша, 31-007, Краков, ул. Голембя, 24; приглашенный исследователь, Санкт-Петербургский государственный университет, Российская Федерация, 199034, Санкт-Петербург, Университетская наб., 7-9; mikolaj.banaszkiewicz@gmail.com

This research was supported by the grant of the Russian Science Foundation No. 19-18-00073 "National Identity in the Imperial Politics of Memory: History of The Grand Duchy of Lithuania and the Polish-Lithuanian State in Historiography and Social Thought of the $19^{\text {th }}-20^{\text {th }}$ Centuries".

Исследование выполнено в рамках гранта Российского научного фонда № 19-18-00073 «Национальная идентичность в имперской политике памяти: история Великого княжества Литовского и Польско-Литовского государства в историографии и общественной мысли XIX-XX вв.».

I express my gratitude to Damian Jasiński for help in translation of the article.

Хотелось бы выразить благодарность Дамяну Ясинскому за его помощь в переводе текста статьи.

(C) St. Petersburg State University, 2021 


\section{М. Банашкевич}

Для цитирования: Banaszkiewicz M. Ladislaus Jagiello in Modern Polish Culture // Вестник СанктПетербургского университета. История. 2021. Т. 66. Вып. 3. С. 828-844.

https://doi.org/10.21638/11701/spbu02.2021.309

Настоящая статья посвящена польским представлениям о Владиславе II Ягелло, великом князе литовском и короле польском, основателе династии Ягеллонов. В последнее время изучение репрезентаций прошлого стало одним из главных направлений тетоry studies. Благодаря им можно взглянуть на исторические события и личности сквозь призму чередующихся эманаций. Калейдоскоп образов прошлого отражает изменения общественного сознания и коллективной памяти данного политического сообщества. Пример Ягелло и неотделимой от его правления Грюнвальдской битвы (1410) - образцовая иллюстрация к вышесказанному. Среди многочисленных представлений о Ягелло особенно глубокий след оставили те, что возникли в XIX в., в период, когда Польша была лишена государственности. Они стали заслугой прежде всего литературы и живописи, а лишь потом политической публицистики и историографии, со временем отразившись в низовых инициативах по сохранению памяти, наиболее ярким проявлением которых стало празднование в 1910 г. в Кракове 500-летия Грюнвальдской битвы. Представления о Ягелло характеризовались антигерманским звучанием, облаченным в исторические одежды и направленным против усиливавшейся германизации. Устроители торжеств хотели вернуться к моментам исторической славы Польши, чтобы пробудить патриотические чувства и тем самым противостоять политике уничтожения национальной идентичности поляков. Произведения Юзефа Крашевского, Генрика Сенкевича, Яна Матейко выполнили свою задачу и стали частью канона, лежащего с тех пор в основе польских представлений, независимо от изменяющихся политических конфигураций. Таким образом, Ягелло стал одной из самых важных фигур в пантеоне польских правителей, а давний исторический опыт (польско-литовская уния) приобрел вневременное измерение, сформировав политическое воображение польской нации. Этот вывод подтверждают и образы Ягелло, представленные в фильмах и исторических сериалах, созданных в Польше в XX столетии.

Ключевые слова: Владислав II Ягелло, Грюнвальдская битва, польско-литовская уния, Тевтонский орден, репрезентации.

\section{Introductory remarks}

The study of changing attitudes to the past, as seen through the prism of representations of historical figures and events, has become firmly established as a topic of historical research in its own right ${ }^{1}$. This has been the case owing to the reflections published in such memory studies journals as History and Memory and Past and Present and to the emergence of specialized periodicals, with Representations as the leading example. Strictly speaking, they do not offer an unprecedented and qualitatively different approach to historiography, but merely expand the repository of tools for the analysis of social awareness in different periods and of collective historical memory. Incidentally, such approaches (albeit without a fully developed conceptual and methodological foundation) were evidently

${ }^{1}$ Cf. Cubitt G. History of Memory // Debating New Approaches to History. London; New York; Oxford; New Delhi; Sydney, 2019. P. 139. 
used in the humanities of the late nineteenth and early twentieth centuries, both in Poland and Russia.

This article deals with Polish cultural representations of Władysław II Jagiełło (d. 1434), Grand Duke of Lithuania and ruler of the Crown of the Polish Kingdom, founder of the Jagiellonian dynasty, whose rule lasted until the late sixteenth century ${ }^{2}$. So far, this issue has been discussed in Polish humanities as an aside to the studies on the place of the Battle of Grunwald of 1410 (and, more broadly, the Polish-Teutonic conflict) in Polish cultural memory ${ }^{3}$.

The peculiarity of Polish historical experience lies in the fact that the Poles gained their modern and fully formed national self-awareness in a period of utter political decline. 'The long nineteenth century', with its characteristic restructuring of social structures and rise of nationalisms, has left its mark in Poland's history as well, but this occurred in the specific circumstances of fragmentation between the Russian Empire, the Austrian Empire and the Kingdom of Prussia. The post-factum views on the Polish-Lithuanian Commonwealth were fundamentally important for Polish self-reflection on the underlying causes of the loss of independence. Naturally, it went beyond assessing the accomplishments or failures of individual rulers. Nevertheless, it was Władysław II Jagiełło, the founder of the dynasty and the founding father of the Jagiellonian idea who was taken into consideration by nineteenth-century historians in their interpretations of the past.

The images of Władysław II Jagiełło discussed below do not form part of a sealed chapter in the history of social thought, one that has been ultimately consigned to the past. On the contrary: as an inalienable part of the intellectual heritage of the Poles, they also constitute their contemporary identity. This is so not only because the images of the past which took shape in the nineteenth century have not been thoroughly questioned on the collective level, but also because their permanent presence in the Polish canon of historical associations has been conditioned by the politics of memory: first of the Second Republic in the interwar period, then of the Polish People's Republic, and now (i.e. after 1989) - of the Third Republic. The impact of Jagiełło's image is ensured by his presence in the repertoire of cultural references in literature, painting, and film, delineating identification with Polishness regardless of the continuous evolution of that term.

\section{Literary portrayals of Władysław Jagiełło}

Let us limit ourselves to the two most important literary portrayals of the founder of the Jagiellonian dynasty. They were written by eminent writers who made their mark in the history of Poland not only as men of letters, but above all as representatives of the immortality of the Polish spirit. The first of these, Józef Ignacy Kraszewski (1812-1887), the most prolific author in the history of Polish literature, remained for a long time a man of multiple undertakings, signalling the Polish presence in the western gubernyas of the

${ }^{2}$ For a brief discussion of the Jagiellonian period and an overview of attitudes to the 'Jagiellonian idea' in Polish historiography, see: Bogucka M. Jagiellonowie // Dynastie Europy. Wrocław, 2003. S. 155-176.

3 See especially: Filler W. "Oto jest olbrzymów dzieło". Grunwald w polskiej literaturze i sztuce. Toruń, 2005. S. 50-65; Kosman M. Krzyżacy w historii i legendzie wieków. W 600 rocznicę grunwaldzkiej wiktorii. Torun, 2010. S. 173-241. - The best systematic study of the image of the Teutonic Knights in Polish collective historical memory is the synthesis written by I. Kąkolewski: Kąkolewski I. Krzyżacy. Przeklęci i bohaterowie // Wyobrażenia przeszłości. Polsko-niemieckie miejsca pamięci. Warsaw, 2017. S. 81-86, 91-95. 
Russian Empire, and acted as a living example of the appeal of Polish culture in the Byelorussian, Lithuanian and Ukrainian lands, where he lived in various periods of his life. In Kraszewski's rich literary output, historical novels do not occupy a prominent place: according to the estimates offered by literary historians, he wrote 94 works set in the past. Nevertheless, in popular consciousness he is considered the leading representative of this genre, making such authors as Julian Ursyn Niemcewicz (1758-1841) or Henryk Rzewuski (1791-1866) pale into insignificance ${ }^{4}$.

Although medieval themes were present in Kraszewski's prose, in terms of quantity they were significantly inferior to those of the late modern period. The figure of Jagiełlo is found in various works by Kraszewski. His attitude towards the founder of the Jagiellonian dynasty evolved, although it never became unambiguously positive. In his poetic trilogy on the history of Lithuania written between 1840 and 1845, Jagiełło is decidedly overshadowed by Vytautas, whose qualities as man and leader are particularly emphasised ${ }^{5}$. Kraszewski treated Jagiełło far more favourably in his much later novel Semko. Czasy bezkrólewia po Ludwiku (Jagiełło and Jadwiga), which he published in 1881. Although Jagiełło's distrustful attitude and his procrastination in making important decisions are given short shrift also in that novel, his far-sightedness and consistency in pursuing the idea of the Polish-Lithuanian union are duly noted ${ }^{6}$.

As for the dissemination of Jagiełł's literary image, the novel Krzyżacy 1410. Obrazy $z$ przeszłości (The Teutonic Knights 1410. Images from the Past), published in the Warsaw periodical Kłosy in 1874, played an incomparably greater role. The fact that it was not included in the monumental series titled Dzieje Polski (The History of Poland) did not detract from its importance, considering the context in which it was written. Like the vast majority of historical fiction, it was written after the January Uprising ${ }^{7}$, but the thrust of his critique was aimed against Germany, not the Tsardom. At that time, the writer had been living for more than a decade in Dresden, where he moved in 1862 in the wake of his conflict with Aleksander Wielopolski (1803-1877). Negatively impressed by Germanisation, which he observed at close quarters, Kraszewski softened his tone towards Russia and made the German threat the leitmotif of his writing and journalistic activity ${ }^{8}$. In this sense, the constantly recurring motif of the Drang nach Osten was clearly presentist in character and expressed day-to-day and palpably real concerns. As Polish youth was de-

${ }^{4}$ Kraszewski's literary output was not entirely unknown in pre-revolutionary Russia. Beginning in the late 1830s, his writings appeared in the most important literary journals. See: Prokofiewa D. A.Z historii publikacji utworów J. I. Kraszewskiego przez prasę rosyjską w latach 1830-1850. Chronologia i tło społeczno literackie // Józef Ignacy Kraszewski. Twórczość i recepcja. Lublin, 1995. S.333. - In addition, entries on Kraszewski were also included in Russian encyclopaedias.

5 Opacka A. Litewska epopeja J.I. Kraszewskiego. Szkice o "Anafielas". Katowice, 1988. S.75-76, 88, 91. See: Szulska I. Litwa Józefa Ignacego Kraszewskiego. Warsaw, 2011. S.219-220. - I. Szulska notes that Kraszewski also described Jagiełło in negative terms in his other writings, including the long poem "Kiejstut 1382 ", the novel "Witoldowe boje", and his memoirs.

${ }^{6}$ Kosman M. Henryka Sienkiewicza wizja Polski wspaniałej. Studia i szkice. Poznań, 1999. P.168169. - Incidentally, it is worth mentioning that in the literary treatment by Kraszewski the joint PolishLithuanian expansion into Rus' was presented as a marginal motive of the Commonwealth's architects; see: Danek W. Powieści historyczne J. I. Kraszewskiego. Warsaw, 1966. S. 73.

7 Jarowiecki J. Powieści historyczne Ignacego Kraszewskiego (geneza i klasyfikacja) // Rocznik Naukowo-Dydaktyczny Studium Terenowego Krakowskiej WSP w Rzeszowie. Nauki Humanistyczne. 1961. Nr 1.S. 143.

${ }^{8}$ Kosmanowa B. J. I. Kraszewski. Syndrom wroga // Kraszewski mniej znany. Studia i szkice. Bydgoszcz, 1998. S. 144. 
prived of access to patriotic historical education, Kraszewski's works filled an important gap in their education ${ }^{9}$. Thus, the literary portrayal found in his novel substituted for historical knowledge about Jagiełło and his times ${ }^{10}$.

The image of Jagiełło in Krzyzacy 1410 is fairly ambiguous. The Polish king is portrayed as a hesitant ruler, often succumbing to his court when making decisions. This concerns key political issues: declaring war on the Teutonic Order, of which - in Kraszewski's novel - he was not in favour; deciding whether to continue the war after the Battle of Grunwald or to besiege the castle at Malbork. In the Teutonic Knights' view, this was due to the Jagiełło's weak character, while in the view of the Polish characters of the novel, it was a result of the excessive magnanimity on the part of the monarch ${ }^{11}$. Kraszewski describes Jagiełło as a very pious man, a person eager to observe all religious principles. The king delays the battle to attend one more Mass, and afterwards gives credit to God for the victory ${ }^{12}$. This attitude is counterbalanced by accusations raised against the king, which stated that he was a secret worshipper of Perun, and that Jagiełło's love for the forest stemmed from his desire to engage in rituals performed under time-honoured oaks ${ }^{13}$. Although the narrator does not sympathize with these allegations, he does not cover up the remnants of paganism in Jagiełło's behaviour, such as his fear of being cursed by a witch. The king's erotic interest in women is also emphasised ${ }^{14}$. In essence, Jagiełło is portrayed as an imperfect man and weak-willed ruler.

That particular novel by Kraszewski was published in book form in 1882, and was not brought to the attention of readers of the newly independent Poland until 1929. Both those editions came out without a preface or afterword, but the novel had many editions after the Second World War, serving as a warning against the Germans and as an argument for the geopolitical orientation towards the alliance with the Soviet Union that was supposed to secure the Polish state against the 'revisionism' of its western neighbour. A telling testimony to such reading of Krzyzacy 1410 was the introduction to the first post-1945 edition of the novel, which saw a number of similarities between the political circumstances that occurred after the 1410 victory at Grunwald and after the war with the Third Reich ${ }^{15}$. Under the Third Republic it was printed only once, in 2010, possibly with a view to eliciting interest from readers on the occasion of the $600^{\text {th }}$ anniversary of the Battle of Grunwald.

However, the image of Jagiełł in the Polish collective imagination was dominated not by Kraszewski's work regardless of its popularity but by Henryk Sienkiewicz's (1846-1916) novel Krzyżacy (The Teutonic Knights). It came out in instalments between 1897 and 1900, appearing simultaneously in several magazines and newspapers: Słowo and Tygodnik Ilustrowany in Warsaw, Dziennik Poznański and Kurier Poznański in Poznań, and Gazeta Lwowska in Lviv, and was released in book form in $1900^{16}$. It is worth emphasising that

9 Burkot S. Józefa Ignacego Kraszewskiego literatura dla "powszechności" // Kraszewski. Studia historycznoliterackie. Warsaw, 1988. S. 28-29.

${ }_{10}$ Still later, the topic of the Lithuanian-Teutonic conflict formed the background to his other epic work: Kraszewski J.I. Kunigas. Powieści z podań litewskich, Warsaw, 1882. 225-226.

${ }^{11}$ Kraszewski J. I. Krzyżacy 1410. Obrazy z przeszłości. Katowice, 1983. S. 52-53, 69, 84, 160, 200, 206,

12 Ibid. S. 129, 134-135, 151, 153.

13 Ibid. S. 17, 46, 94.

14 Ibid. S. 47, 231.

15 Od wydawnictwa // Kraszewski J. I. Krzyżacy. Obrazy z przeszłości 1410 roku. Łódź; Wrocław, 1947. S. 5-8.

16 Żabski T. Sienkiewicz. Wrocław, 1998. S. 252. 
Kraszewski's novel was an important point of reference for Sienkiewicz as he published an extensive review of it $^{17}$. Sienkiewicz's monumental work constituted an artistic response to the Kulturkampf in the Polish lands under the Prussian rule to an even greater extent, formulated as it was by an external observer who had not known it first-hand. The concept for the novel took many years to develop. It was based on the conviction that the newly established German Empire, the work of the 'Iron Chancellor', Otto von Bismarck (1815-1898), was just another emanation of the centuries-old drive of the Germanic element to expand eastwards. The policy of the Teutonic Order was perceived as a universally recognised blueprint for that expansion ${ }^{18}$.

The stunning success of Krzyżacy owes much to the literary convention adopted by Sienkiewicz. As an adventure novel of undoubtedly aesthetic value, coupled with a prominent romance plot, it instantly enraptured the reading public ${ }^{19}$. The faithfully depicted historical background, a signature characteristic of Sienkiewicz's writing, who was to become a Nobel Prize winner, immediately contributed to the book's didactic significance. In this respect, the author owed most to the fundamental work of Karol Szajnocha (1818-1868) entitled Jadwiga i Jagiełto 1374-141320. The closing event in the book, i. e. the year of the Polish-Lithuanian pact signed in Horodło, demonstrates that it was the commonwealth of Poland and Lithuania, rather than the fate of their rulers, that was the topic of Szajnocha's considerations ${ }^{21}$. The fifteenth-century chronicler Jan Długosz (1415-1480) and his History of Poland also served as an important source of inspiration for Sienkiewicz, its lasting value being that Długosz had seen Jagiełło, who was then at an advanced age, and drawn much information about his reign directly from Zbigniew Oleśnicki (1389-1455), a grey eminence at the royal court at the time. Incidentally, it is worth mentioning that Szajnocha's work mentioned above was made available to Russian readers in a translation by Vladimir V. Chuyko (1839-1899) on the initiative of the Russian publishing tycoon Bolesław Maurycy Wolff (1825-1883) 22 .

Strictly speaking, the time frame of the novel's narrative is marked by the death of Queen Jadwiga (1399) and the Battle of Grunwald (1410) ${ }^{23}$. The final caesura is not a mat-

17 See: Sienkiewicz H. Mieszaniny literacko-artystyczne. Warsaw, 1950. S. 120-144. - For a comparative analysis of the images of the Battle of Grunwald and Jagiełlo in the writings of these two authors, see: Hofman I. "Krzyżacy 1410" J. I. Kraszewskiego a "Krzyżacy” H. Sienkiewicza // W stulecie Krzyżaków Henryka Sienkiewicza. Kielce, 2000. S. 287-292.

18 Krzyżanowski J. Twórczość Henryka Sienkiewicza. Warsaw, 1973. S. 195, 240-241.

19 For a literary analysis of the novel, see: Krzyżanowski J. Henryka Sienkiewicza I. "Krzyżacy”. Powieść klasyczna // Krzyżanowski J. Pokłosie Sienkiewiczowskie. Szkice literackie. Warsaw, 1973. P. 344-366. — For a Russian perspective on Sienkiewicz's writing, see: Gorskii I. K. Pol'skii istoricheskii roman. Moscow, 1963.

${ }^{20}$ Szajnocha K. Jadwiga i Jagiełło. 1374-1413. Opowiadanie historyczne. Lwów, 1855-1856 (first printing; amended in 1861). - See also a discussion of Szajnocha's writings by the author of the critical edition of that text; one will find there a more considerate assessment of Jagiełło: Kuczyński S. M. "Jadwiga i Jagiełło" Karola Szajnochy na tle jego życia i twórczości naukowej // Szajnocha K. Jadwiga i Jagiełło 13741413. Opowiadanie historyczne. T. 1-2. Warsaw, 1974. S. 31-36, 52.

21 Julkowska V. Historia dla wyobraźni. Recepcja i interpretacja pisarstwa historycznego Karola Szajnochy. Poznań, 2010. S. 75, 280.

22 Shainokha K. Iadviga i Iagailo. T. 1-2. St. Petersburg; Moscow, 1880.

${ }^{23}$ In fact, the time frame should be extended to between 1331 and 1466. The former is associated with the Battle of Płowce (when Polish troops defeated the Teutonic Knights), while the latter indicates the signing of the Torun Peace Treaty, which confirmed Poland's victory in its struggle with the Teutonic Knights. See: Ludorowski L. Wizjoner przeszłości. Powieści historyczne Henryka Sienkiewicza. Lublin, 1999. S. 220 . 
ter of coincidence: alongside his signature literary triptych (commonly known in Poland as 'the Trilogy'), the novel Krzyżacy was intended by its author to boost the national sentiment of the Poles. Sienkiewicz endowed his historical novel with additional, non-literary functions. It was meant to convey to the reader the timeless values that made up the immortal Polish idea. Recalling moments of glory from the distant past, it compensated for the lost statehood. Contrary to the historical fact, the victory in the Battle of Grunwald is presented in the novel as the decisive event that settled Poland's struggle with the Teutonic Order. Moreover, Sienkiewicz's novel imparted on that event a symbolic, historiosophical and perhaps even sacred meaning. The readers of Krzyzacy could thus see Grunwald as an inkling of the future political power of the Polish-Lithuanian Commonwealth, in the construction of which the Polish religious and civilising mission played a significant role; they could also see it as proof that the then German superiority could be overcome in the future ${ }^{24}$.

The literary portrayal of Jagiełło in the novel can be considered in two specific dimensions. Firstly, his character is reflected in the opinions of both his subjects and his opponents (i.e., the Teutonic Knights). Secondly, his image shines through the few scenes in the novel in which he appears. In truth, however, the reader gets to know the king better only on the battlefield; his earlier appearances in the novel are only episodical. Sienkiewicz presents the monarch as an impetuous, irascible and impatient man, who nevertheless consciously corrects his behaviour in such a way as to make it correspond to the image of a commendable ruler ${ }^{25}$. Jagiełło's greatest weakness is his fear of being accused of favouring paganism ${ }^{26}$. The propaganda of the Teutonic Knights eagerly exploited this ${ }^{27}$; the king's supporters were also aware of this characteristic and referred to it intepreting Jagiełło's reluctance to declare war on the Teutonic Knights ${ }^{28}$. This was supposed to explain his ostentatious piety, which manifested itself in his attending several masses a day. Emphasis was also placed on the king's lability, or rather hesitation in taking responsible decisions. His personal setbacks paralysed him and turned him into an escapist ${ }^{29}$. Jagiełło clearly gains momentum in a decisive moment. Sienkiewicz shows the transformation of a monarch who finally manages to carry the burden of responsibility for commanding the battle. His contribution to the victory at Grunwald is accentuated, along with his chivalrous virtues that he proved on the battlefield. Finally, he is portrayed as a magnanimous monarch who is unwilling to seek revenge on the defeated knights of the Teutonic Order, including the dead body of the Grand Master, to which he granted a funeral. However, in Sienkiewicz's novel, the joy of victory does not affect the propensity for reflection on the king's part: the tears rolling down his cheeks emphasise his reluctance to cause bloodshed, a signature trait of a good Christian ruler ${ }^{30}$.

Sienkiewicz's literary representations of Jagiełło and of the victory at Grunwald have long shaped the Polish collective imagination, and are a cornerstone of traditional pat-

${ }^{24}$ Bujnicki T. Wstęp // Sienkiewicz H. Krzyżacy. Wrocław, 1990. S. XI, XVII-XVIII, XXXVII, XLIIXLIII, LXX; Bujnicki T. Od "Krzyżaków" do "Srebrnych orłów" // Sienkiewicz i historia. Studia. Warsaw, 1981. S. 208-209.

25 Sienkiewicz H. Krzyżacy. Wrocław, 1990. T. 1. S. 80; T. 4. S. 79.

${ }^{26}$ Ibid. T.1. S. 92.

27 Ibid. T. 4. S. $107-108$.

28 Ibid. S. 153.

29 Ibid. T.1. S. 119.

30 Ibid. T. 4. S. 235-236, 243-244. 
riotism, which draws extensively on nineteenth-century models. At times, they give rise to a polemic concerning the Polish national idea. One example is Szczepan Twardoch's 2010 novel, postmodern in form and iconoclastic in content. The subject of the author's critical reflection is the 'timeless' Polish-German conflict ${ }^{31}$. The latest attempt to use the founder of the Jagiellonian dynasty in a literary work was a theatre play with strong presentist tendencies (the action takes place at night from 10 to 11 April 2010, after the crash of the Polish government plane in Smolensk). Jagiełło and Jadwiga appear in it as resurrected commentators of Polish-Lithuanian history ${ }^{32}$. The work has gone unnoticed.

\section{Images of Jagiełlo in painting: the perspective of Jan Matejko}

Among the surviving depictions of Jagiełło, the closest to authenticity is the monarch's head on the sculpted tombstone in Wawel Cathedral ${ }^{33}$. Less reliable, although close to the original, are two portraits preserved in the frescos of the Castle Chapel in Lublin. In one of them, Jagiełło is depicted as kneeling, while in the other, he is mounting a galloping horse. Both images were drawn by Ruthenian painters ${ }^{34}$. Of course, in the centuries to follow, other images were made, referring to those from Jagiełło's time. The best-known portrait of the king was painted by Marcello Bacciarelli (1731-1818), the court painter to King Stanisław August Poniatowski (1732-1798); the picture is part of Bacciarelli's set of portraits of Polish monarchs (painted between 1768 and 1771) and is displayed in the Marble Room at the Royal Castle in Warsaw.

However, the popular notions about Jagiełło are not connected with the above-mentioned paintings, but with the representations created by Jan Matejko (1838-1893), the founder of the national school of history painting. The decision to confine the discussion here to the work of just one painter is justified by the extraordinary role he played in shaping Polish national awareness. To this day, Matejko's work in Poland is synonymous with painting as such, and his paintings are highly evocative for all Polish viewers, regardless of their education. The works of the Kraków artist were widely disseminated in the form of reproductions, strongly influencing their recipients, including those from the lower social strata who did not identify themselves with the Polish idea. Matejko has become a history teacher of sorts to successive generations of Poles, even though the message of his paintings and his manner of artistic expression were seen as anachronistic by his contemporaries $^{35}$.

The impact of Matejko's vision on the hearts and minds of Polish viewers was not purely artistic in nature. In fact, his works had a profound historiosophical background, which was openly stated in his own theoretical discourses. It has been argued in the scholarly literature on the subject that Matejko was not so much a historical painter, but rather a myth-maker ('myth' is understood here as the collective dream of a national communi-

31 Twardoch Sz. Wieczny Grunwald. Powieść zza końca czasów. Warsaw, 2010.

${ }^{32}$ Mond-Kozłowska W. Władysław II Jagiełło. Dyptyk jagielloński. Skrzydło drugie. Cracow, 2011. For a review of this play, see: Dehnel J. Młodszy księgowy. O książkach, czytaniu i pisaniu. Warsaw, 2013. S. 76-80.

${ }^{33}$ For a discussion of the alleged late fifteenth-century portrait of Jagiełło as one of the three Magi in the Holy Cross Chapel of Wawel Cathedral, see: Karkut D. Wizerunki Władysława Jagiełły w literaturze i malarstwie // Zeszyty Naukowe Uniwersytetu Rzeszowskiego. Seria filologiczna. 2014. Nr 86. S. 72-73.

${ }^{34}$ Krzyżaniakowa J., Ochmański J. Władysław II Jagiełło. Wrocław, 1990. S. 344-346.

35 Słoczyński H. M. Matejko. Wrocław, 2000. S. 224-228. 
ty). Therefore, his paintings should be interpreted allegorically, instead of being analysed through the prism of historical accuracy ${ }^{36}$. It is beyond doubt that his work was based on a solid messianic foundation, which made it very attractive for those who sought consolation and remedy for the current misery in Poland's glorious days.

It would be hard to find a clearer embodiment of Matejko's vision than in the monumental oil painting Bitwa pod Grunwaldem (The Battle of Grunwald), painted between 1872 and 1878 (now in the collection of the National Museum in Warsaw). The painting, shown, among others, at an exhibition in St Petersburg in 1879, depicts Jagiełło in armour, riding a horse, in the upper right corner. Although his figure is not as prominent as that of Vytautas, which dominates in the painting's centre, this does not deny his merits in the victory as the content of the painting is the triumph of Polish troops over the enemy. It was a victory not only in a military but also in a spiritual sense as suggested by the figure of St Stanislaus - a patron saint of Poland and a martyr - hovering over the battlefield ${ }^{37}$. The mythologizing value of the work invariably remains an interesting research topic and is subject to new interpretations, which imparts new meanings to the painting. As a Polish art historian put it, "'the presented world' of Matejko's Battle exists... outside real time and space, and is delimited by the artistic space-time which relates the 'thematic event' to the sphere of meanings and values" 38 . It is also worth noting that with time the anti-German connotation of The Battle of Grunwald gained an ethical dimension, making the military aspect recede into the background ${ }^{39}$.

The most famous painting inspired by Matejko's work was Grunwald (1931) by Wojciech Kossak (1856-1942) commissioned by the National Museum in Warsaw. In the opinion of critics, the famous battle artist did not rise to the challenge ${ }^{40}$. The fact that the subject still evokes emotions is proved by the response to the exhibition Grunwald w sztuce. Co po Matejce? (Grunwald in Art. What comes after Matejko?) displayed at the Museum of Warmia and Mazury in Olsztyn in $2010^{41}$. Matejko's painting has become an integral part of the Polish cultural code. Its recognisability means that it is often used in commercial ventures. For example, the Polish puzzle manufacturer Castorland, also present on the Russian market, offers a jigsaw puzzle with The Battle of Grunwald consisting of 600 elements $^{42}$.

Despite the place The Battle of Grunwald occupies in the Polish collective memory, the first association with Jagiełło is his image in the Polish Kings and Princes series created by Matejko, which consisted of drawings of rulers created between 1890 and 1892, i. e.

36 Porębski M. Czy Matejko był malarzem? // Wokół Matejki. Materiały z konferencji Matejko a malarstwo środkowoeuropejskie zorganizowanej w stulecie śmierci artysty. Cracow, 1994. S. 22.

37 Krawczyk J. Matejko i Historia. Warsaw, 1990. S. 127-128.

38 Okoń W. Sztuka i narracja. O narracji wizualnej w malarstwie polskim II połowy XIX wieku. Wrocław, 1988. S. 95.

39 Poprzęcka M. Grunwald and Grunwald // Jan Matejko's Battle of Grunwald. New Approaches. Warsaw, 2010. P.32.

40 Olszański K. Wojciech Kossak, Wrocław, 1982. S.44. - For other painters' visions of the battle of Grunwald, see: Janczyk A. „Bitwa pod Grunwaldem” Tadeusza Popiela i Zygmunta Rozwadowskiego // Spotkania z zabytkami. 2010. Nr 5-6 (279-280). S.11-15; Wołosz A. K. F.: 1) Matejko nie był ani pierwszy, ani ostatni, czyli kilka uwag o niektórych przedstawieniach bitwy pod Grunwaldem od XV do XXI w. // Ibid. S. 2-10; 2) Krakowska diorama „Grunwald” Jana i Tadeusza Styków // Ibid. S. 16-20.

${ }^{41}$ Wystawa Grunwald w sztuce. Co po Matejce? URL: http://leksykonkultury.ceik.eu/index.php/ Wystawa_Grunwald_w_sztuce._Co_po_Matejce\%3F (accessed: 01.09.2020).

42 URL: https://www.castorland.pl/pl/puzzle/b-060382 (accessed: 01.09.2020). 
over a dozen years after The Battle of Grunwald had been completed. The monarch was depicted as a representative of a foreign culture, a representative of Eastern (Lithuanian and Ruthenian) lands. Such was the image of the founder of the Jagiellonian dynasty in two other paintings featuring Jagiełł: Założenie Szkoły Głównej z przeniesieniem do Krakowa ugruntowane. R. P. 1361-1399-1400 (The Founding of the University and its Transfer to Krakow) (1889) and an illustration in the Ubiory w Polsce (Polish Dress) album (1860) ${ }^{43}$. Other two depictions of the founder of the Jagiellonian dynasty are the painting Ladislaus Jagiello with Witold Praying Before the Battle of Grunwald (National Museum in Warsaw) and the watercolour Ladislaus Jagiello in the Battlefield of Grunwald (National Museum in Kraków). Their subject matter is yet another proof that in the popular perception the figure of the monarch is mainly associated with the Battle of Grunwald. In the first one (1855), Jagiełło is entirely engrossed in prayer and does not react to Vytautas' urging to start the battle. In the second one (1861), the tall and slim king is leaning on a sword. As the official commentary to the exhibition explains, "his cameral composition, compared to the oil painting from 1878, sketched by Matejko, shows the pathos and dignity of Polish-Lithuanian triumph over the enemy" 44 .

\section{Jagiełło on a TV screen}

Although the founder of the Jagiellonian dynasty is not one of the most popular characters in Polish historical films and TV series, he has always been portrayed much more favourably on screen than in fiction. The film adaptation of Sienkiewicz's Krzyżacy directed by Aleksander Ford (1908-1980) has immensely influenced the reception of Jagieło. Released to the public in 1960, it turned out to be the production with the largest audience in the history of Polish cinema. It fitted in with the politics of memory of the Polish People's Republic, which was based on evoking patriotic sentiments, particularly referring to anti-German attitudes. Compared to the novel, it additionally emphasised Jagiełło's role in the victory at Grunwald, marginalising Vytautas and the Lithuanians. Not surprisingly, screenings of the film in Lithuania provoked negative reactions from the local audience ${ }^{45}$. The historical consultant of the film, Stefan M. Kuczyński (1904-1985), was the master figure promoting the appreciation of Jagiełło as an astute politician and a great leader ${ }^{46}$. As a fervent admirer of the king, he wrote numerous books and studies to counter the critical assessments of Jagiełło's reign in Polish historiography and historical fiction. Despite the passage of time and several bold announcements along the way, no attempt has been made thus far to produce yet another film rendition of Sienkiewicz's Krzyżacy ${ }^{47}$.

${ }^{43}$ For an analysis of the heraldic emblems in the paintings in question, see: Światek A. "Lach serdeczny". Jan Matejko a Rusini. Cracow, 2013. S. 92-94.

44 Temporary exhibition "Jan Matejko. Various stories", displayed at the Jan Matejko House in 2020. See: URL: https://mnk.pl/exhibitions/jan-matejko-various-stories (accessed: 01.09.2020).

45 Gudavičius E. Między kultem a rzeczywistością: rozważania o postrzeganiu Witolda Wielkiego w historiografii i społeczeństwie litewskim // Tematy polsko-litewskie. Historia - literatura - edukacja. Olsztyn, 1999. S. 64.

46 Tomkiewicz R. Film Krzyżacy Aleksandra Forda // Komunikaty Mazursko-Warmińskie. 2010. Nr 2. S. 176; Skowronek B. Film Krzyżacy Aleksandra Forda. W uścisku rozmaitych ideologii // Res Gestae. Czasopismo Historyczne. 2011. T.11. S. 191.

47 A digitally retouched version of the film is available online on the official YouTube channel of the Polish Information Agency (Polonijna Agencja Informacyjna). See: URL: https://www.youtube.com/ watch? =I6a0CGTeWV0 (accessed: 01.09.2020). 
The film image of Jagiełło as a ruler (with Emil Karewicz, 1923-2020, playing this role) exudes severity and fairness. Unlike in the novel, the king is not hesitant about sentencing the main protagonist to death for offending a Teutonic envoy $\left(100^{\prime}-102\right.$ '). Grim countenance and stern tone of voice add up to his majestic grandeur $\left(17^{\prime}-20^{\prime}\right)$. Similarly, the king not only disagrees with his advisors, but even persuades them to adopt his own point of view on the armed conflict with the Teutonic Knights; moreover, it is from the very beginning that he believes in the possibility of defeating them by striking "an alliance with Lithuania and Rus" (103'-105'). He is also portrayed as the chief strategist in the Battle of Grunwald, the only author of the battle plan, which is unconditionally obeyed by everyone, including Vytautas $\left(149^{\prime}-152^{\prime}\right)$. Particularly moving are the scenes when he looks at the future battlefield, standing on his own, crosses the swords received from the Teutonic Knights' envoys, foreseeing his victory, and pensively comments on the fate suffered by the opponents on the battlefield in the final scene of the film $\left(1533^{\prime}, 157^{\prime}-159^{\prime}\right.$, 172 ').

The enduring interest in the times of Jagieło and in himself as a historic figure is demonstrated by the eight-episode series Królewskie sny (Royal Dreams) made in 1988 by Grzegorz Warchoł (b. 1947), based on a script by Józef Hen (b. 1923), a distinguished writer, playwright, and columnist. The series deserves to be discussed in more detail, because it is in this series that Jagiełlo's characteristics are clearly communicated, in a manner that significantly differs from the other portrayals. As the scriptwriter wrote in his memoirs, his Jagiełło was intended to be "warm, fatherly, with a wise and sceptical smile" 48 . The noble features of the king's image were undoubtedly enhanced by the memorable role of Gustaw Holoubek (1923-2008), which ensured the series' status of a masterpiece of Polish historical film ${ }^{49}$. Aleksander Gieysztor (1916-1999), a towering figure among Polish historiographers, commented very favourably on the script's consistency with historical reality.

The story line of the series begins in 1420, after the passing of Jagiełło's third wife. The viewer thus follows the last years of the king's life shown against the background of the political history and everyday life. The king is portrayed in two interlinked aspects, private and public. As a man, his gentleness is exemplary (as in the wedding night scene: episode 2,56 ' et seq.); his hesitant and caring attitude towards women, especially to his fourth wife Zofia Holszańska (1405-1461) and daughter Jadwiga (1408-1431) is noteworthy. He enjoys spending time with his family and, most remarkably, does not give in to erotic temptations in his dealings with other women. He is very much affected by Zofia's alleged marital infidelity (episode 5). He is aware that some consider him to be a philistine, which is counterbalanced by his meetings with his impetuous brothers (especially with Świdrygiełło (1370-1452), e.g. episode 7,33’ et seq.), which clearly demonstrates Jagiełło’s

${ }^{48}$ Hen J. Nie boję się besennych nocy... Z księgi drugiej. Warsaw, 1992. S. 185. - Elsewhere in his memoirs, Hen mentions a telephone call from Franciszek Szlachcic (1920-1990), former interior minister of the Polish People's Republic, who said to him that all dignitaries... should watch this series to learn how Poland should be governed' (Ibid. S.267).

49 The series is available online. See: URL: https://vod.tvp.pl/website/krolewskie-sny,37244878 (accessed: 01.09.2020). The script for the series gave rise to the book: Hen J. Królewskie sny. Warszaw, 1989. Second edition came out in 2018 published by Sonia Draga Editions. For a review thereof, see e. g.: Stanek M. Król mędrzec i błazen (Józef Hen "Królewskie sny"). URL: http://www.zaokladkiplotem.pl/2017/12/krolmedrzec-i-bazen-jozef-hen.html; Królewskie sny. URL: https://literatkakawy.wordpress.com/2018/03/31/ krolewskie-sny/ (accessed: 01.09.2020). 
virtues: sobriety (he does not drink alcohol), calm, unbiased perspectives, and supreme intellect. The peculiarity of the king's religiousness is also evident: despite the many years that have passed since his baptism, he is unable to abjure paganism in stressful situations.

The portrayal of Jagiełło as a man corresponds in the series with his qualities as a statesman. His maturity, perspicacity, ability to reconcile opposing political views, and far-sightedness are given pride of place. For instance, in episode 4, 50'-51', he states sententiously: "Our wisdom comes from what is imprinted in our memory and yet from something that is inside me, and tells me what I should do". In reality, the king is manoeuvring between individual coteries, trying to balance their influence through official nominations. He often shows generosity by refraining from punishing disloyalty. A certain crack on his image as a ruler is his excessive propensity for reflection, which makes it difficult for him to take firm decisions. This does not imply, however, that the image of Jagiełło in the series is that of an indecisive and dependent leader. On the contrary, he forcefully condemns the brutal crackdown on paganism (episode 2, 31' et seq.), tries to limit the influence of the Catholic hierarchs in the Royal Council, justifying the alliance with the Hussites by foreign policy considerations. He respects the legal culture of the Crown and fully identifies himself with its interests. However, he has a different stance on Lithuania, compared to his advisors; after Vytautas' death, he is against applying radical measures against the Grand Duchy because, in his opinion, this would only expedite its fragmentation due to the natural inclination of the Ruthenian elites towards the East. His diplomatic talents do not prevent him from concluding in his final days that "the history of rulers is replete with crime, lies and deceit" (episode 8, 20').

The portrayal of Jagiełło in the Królewskie sny series is the most comprehensive and positive representation of this monarch in Polish popular culture. However, the old-fashioned style of the series compared to modern Western productions makes it difficult to be received by young viewers. Their needs are to be satisfied by the historical series Korona królów (The Kings' Crown), whose title is a reference to Game of Thrones, an HBO hit production. The producer of that historical soap opera (the episodes last about 25 minutes, and their number is nearing four hundred) is Polish Television. The intention of the series' creators is to acquaint viewers with the medieval history of Poland, from the last Piasts through the Anjou to the first Jagiellons. The series premiered in January 2018. Public reactions are very diverse and indicative of the main political division in Poland between supporters and opponents of the ruling Law and Justice party. The production is treated and perceived as a manifestation of the new politics of remembrance pursued by this group in opposition to the previous governments of the Third Republic accused by Law and Justice of educating youth in the spirit of the 'pedagogy of shame'. The idea of the series has been to show Polish history in a positive light. At the time of writing the article the final episodes of the third season featuring Jagiełlo had not yet been broadcast (the current coronavirus pandemic disrupted the filming of the planned episodes). However, it is known that his role is played by the Ukrainian actor Vasyl M. Vasilyk (b. 1986). The fourth season, dealing with the reign of Jagiełło after the death of Queen Jadwiga, is announced for release in autumn $2021^{50}$.

${ }^{50}$ All episodes are freely available online. See: URL: https://koronakrolow.vod.tvp.pl/ (accessed: 01.09.2020). 


\section{Jubilee celebrations of the Battle of Grunwald (images of Jagiełło)}

Literature and the fine arts have preserved the memory of the successful outcome of the fifteenth-century conflict with a country whose successor was one that was among the superpowers that partitioned Poland. Perhaps it would be more apposite to say that they have not so much preserved, but rather evoked it or even created it anew. Obviously, it was not the talent of the artists or the evocative character of their works that determined the success of this undertaking but the widespread opposition to Germanisation implemented by successive Prussian governments. Regardless of which factor played a decisive role in cultivating that sentiment ${ }^{51}$, there can be no doubt that anti-German attitudes were shared by Polish subjects of all three partitioning powers. The jubilee celebrations in Kraków on 15 July 1910 were perhaps the most striking expression of the anti-German sentiment ${ }^{52}$. Their character and, above all, their resonance among Poles, including among those who remained in exile, bear unquestionable testimony to this.

The centrepiece of the so-called 'Grunwald celebrations' was the unveiling of a 24-metre-high equestrian statue of Jagiełło on Matejko Square in the very centre of the city, opposite the historic Floriańska Gate. The sculpture by Antoni Wiwulski (1877-1919) was founded by Ignacy Jan Paderewski (1860-1941), the famous pianist and future Prime Minister of the Second Republic of Poland ${ }^{53}$. Preparations for the setting up and unveiling of the monument were kept secret for fear of preventive action by the Austrian administration (it was a thorn in the side of the Germans which was evidenced by the fact that the Nazi invaders set about demolishing it as soon as the Third Reich authorities were installed in Kraków). The scale of the jubilee exceeded all expectations: the event attracted 150,000 people and became a great patriotic manifestation, in which Poles from all the partitions took part.

A telling example of the impact of the Grunwald celebrations on the attitudes of Poles can be found in the coverage of the events by Dziennik Petersburski (The Petersburg Daily). At the time, it was one of the two daily newspapers published in Polish on the territory of Russia (outside the Kingdom of Poland). Ideologically, it leaned towards liberal democracy, and over time became a media outlet supporting the Piłsudski camp ${ }^{54}$. It might have seemed that, in distant St Petersburg, the subject of Grunwald would be of little interest to anyone, but the reality proved this assumption wrong: several extensive reports were published in relation to the anniversary celebrations in Kraków, and the battle itself became a pretext for general reflections on Polish political culture and the current situation of Poles. The editor of the journal credited the victory at Grunwald ("the inextinguishable glory of Poland and Lithuania") primarily to "Jagiełło’s diplomatic and political talent"55.

The most eloquent expression of the homage to the king was the fact that the daily newspaper reprinted the speech by the state marshal of Galicia, Count Stanisław Badeni

51 Ferro M. Resentyment w historii. Warsaw, 2013. S. 8-9.

52 See: Urbańczyk A. Pomnik grunwaldzki w Krakowie. Cracow, 1974. S.70-79; Treiderowa A. Obchody grunwaldzkie w Krakowie. Cracow, 1961. S.35-44.

53 As we learn from Paderewski's memoirs, it was since his childhood that he had dreamed about founding the Grunwald Monument; he would set aside a portion of all the royalties for his performances to this end. See: Paderewski I. J. Pamiettniki. Cracow, 1986. S. 450-451.

${ }^{54}$ For an in-depth study of the ideological framework of the daily newspaper, see: Banaszkiewicz M. Dziennik Petersburski // Polski Petersburg. URL: http://www.polskipetersburg.pl/hasla/dziennikpetersburski (accessed: 01.09.2020).

55 Ossendowski A. Grunwald 1410-1910 // Dziennik Petersburski. 1910. 1 (14) July. S. 1. 
(1850-1912), delivered before the unveiling of the monument. It was a veritable encomium of the monarch; Badeni claimed, for instance, that 'the nation owes [to Jagiełło] its development as a state and the very existence". Expanding on this, he explained that the victory at Grunwald made it possible to strengthen the union between Poland and Lithuania, which finally came to fruition in 1569 , and, as a consequence, gave rise to the Commonwealth, a political superpower. This achievement was the 'time-honoured work and merit of King Władysław", and hence, Badeni concluded, 'it is our duty to unveil this monument to the hero to whom we owe the triumph of the Christian idea and Polish culture on the battlefield, which laid a powerful foundation for the future of his own (i.e. Lithuanian. - M. B.) nation"56.

One may wonder, however, to what extent the jubilee contributed to the glorification of the monarch. In this context, it is significant to note that in the introductory article of Dziennik Petersburski written on the occasion of the fifth centenary of the Polish-Lithuanian union in Horodło, Jagiełło is not mentioned at all. Its author glossed over the king despite considering the event itself to have been "the most splendid act of Polish political genius" 57 . In any case, the news of the Kraków celebrations circulated widely, consolidating the Poles, who were then deprived of their own statehood.

After the regaining of independence by Poland in 1918, the Grunwald victory stood little chance of becoming widely celebrated. The politics of memory of the newly independent state was founded on the recent and strongly evocative event known in Poland as the Miracle on the Vistula, i. e. the defeat of the Red Army by the Polish Armed Forces in the Battle of Warsaw (August 1920). Jagiełło himself was commemorated on the fifth centenary of his death (1934) in Działdowo (Warmia and Masuria). Topped with a bas-relief of the White Eagle, the monument by Bohdan Nowak took the form of a hand holding a sword, pointing downwards. Destroyed by the Nazis in September 1939, it was rebuilt in $1994^{58}$. In the interwar period, the monument was a clear manifestation of Poland's politics of memory in the areas whose population had strong ties with Germany.

The most spectacular manifestation of this, however, was another monument commemorating the founder of the Jagiellonian dynasty. The monument of Jagiełlo by Stanisław K. Ostrowski (1879-1947) presented in the Polish Pavilion at the World Exhibition in New York in 1939 was a three-metre-high equestrian statue of the king, swords crossed over his head, placed on a four-metre-high plinth. The monument was very impressive, and was purchased by the city. It was unveiled in Central Park, where it still stands today, on the anniversary of the Battle of Grunwald in 1945. The inscription on it refers to the Polish-Lithuanian Commonwealth. Jagiełło is referred to as 'founder of a free union of the peoples of East-Central Europe"59.

The politics of memory of the Polish People's Republic, especially in its early years, strongly exploited the victory of Grunwald for propaganda purposes. The Nazi occupation was portrayed as a continuation of the havoc wrought by the Teutonic Order and later by the Prussian state. The successive anniversaries of the battle were a memento of sorts, signalling the constant menace of 'Germanism', which was later referred to as 'German

${ }^{56}$ Uroczystości grunwaldzkie // Dziennik Petersburski. 1910. 8 (21) July. S. 2.

57 Al. B-ski [Babiański A.] W rocznicę // Dziennik Petersburski. 1913. 3 (16) October. S. 1.

58 Monument to Władysław II Jagiełło. URL: http://monuments-remembrance.eu/en/panstwa/ polska-2/509-pomnik-wladyslawa-ii-jagielly-2 (accessed: 01.09.2020).

59 Kopczewski J. S., Siuchniński M. Grunwald. 550 lat chwały. Warsaw, 1961. S. 336-339. 
revanchism' and limited only to West Germany, as the German Democratic Republic was part of the socialist bloc. The ideological framework of the celebrations (emphasis on the participation of the popular masses in the victory, on the timeless alliance of the Slavs, on Grunwald as a beacon of hope for the freedom of peoples) completely overshadowed the figure of Jagiełło. Consequently, the celebrations did not contribute to 'popularising' this ruler in historical consciousness. One analysis of the historical semantics of the Poles' perception of Grunwald led to the conclusion that the great celebrations of the $550^{\text {th }}$ anniversary of the battle in 1960 turned out to be the swansong of the Grunwald jubilee frenzy. The communists' attempt to monopolise and transform that patriotic occasion into an internationalist/real-socialist one failed to succeed: the propaganda message touted by the communist authorities was poorly received and did not fulfil its intended role ${ }^{60}$.

Under the Third Republic, the Grunwald celebrations lost their anti-German overtones. Characteristically, the sixth centenary of the Battle of Grunwald in 2010 took the form of a five-day medieval-style fair with numerous outdoor attractions (historical re-enactments, games, sports competitions resembling chivalric tournaments). The geopolitical reorientation of Poland after 1989, boosted by its accession to NATO (1999) and the European Union (2004), has changed the Polish perspective on the geopolitical dimension of the conflict with the Teutonic Knights. This is evidenced by the fact that one objective for the 2010 jubilee, as stated by the National Centre for Culture (Narodowe Centrum Kultury) which financed the celebrations, was to demonstrate the role of the battle in shaping the policy of the fifteenth-century Poland toward the East in the context of the current geopolitical circumstances" ${ }^{\prime \prime}$. The historic figure of Jagiełło has become insignificant; only the permanent determinants of Poland's raison détat turned out to be relevant.

\section{Conclusions}

The presence of Jagiełlo in the canon of historic figures that embodied the greatness of Poland (as can be seen in the 100-zloty banknotes with his image) is a permanent phenomenon in Polish historical consciousness. This is supported both by the artistic level of his portrayals (irrespective of the manner in which he is depicted) and by the school curriculum (which remains unchanged in this respect). In recent years, however, Poland's intellectual elites have been pondering on the need to return to the Jagiellonian idea in Polish foreign policy. We shall see whether in the longer term these ideas, passed down from generation to generation, will withstand the pressing changes in collective memo$\mathrm{ry}^{62}$. As for now, they surprisingly persist despite the alarming warnings of a rapid decline in the humanist culture of Polish society.

60 Traba R. Konstruowanie pamięci. Analiza semantyczna polskich obchodów rocznic grunwaldzkich // Traba R. Historia - przestrzeń dialogu. Warsaw, 2006. S. 219-220.

${ }^{61}$ Dni Grunwaldu 2010. URL: http://leksykonkultury.ceik.eu/index.php/Dni_Grunwaldu_2010 (accessed: 01.09.2020). — For a comparison between the celebrations organized by the Polish People’s Republic and the German attempts at monopolizing the memory of Tannenberg, see: Traba R. Próby państwowej monopolizacji pamięci: Tannenberg 1927 (-1935) - Grunwald 1960 // Polska - Europa - Niemcy. Księga jubileuszowa z okazji siedemdziesiątej rocznicy urodzin Profesora Jerzego Holzera. Warsaw, 2000. S. 492-499.

${ }^{62}$ Kwiatkowski P. M. Jaką historią interesują się Polacy? Pytanie o kształt pamięci zbiorowej i jej przemiany po 1989 roku // Historia Polski od-nowa. Nowe narracje historii i muzealne reprezentacje przeszłości. Warsaw, 2014. S. 119-158. 


\section{References}

Bogucka M. Jagiellonowie. Dynastie Europy. Wrocław, Ossolineum Publishing House, 2003, ss. 155-176. Bujnicki T. Sienkiewicz i historia. Studia. Warsaw, Państwowy Instytut Wydawniczy Publ., 1981, 269 s. Bujnicki T. Wstęp. Sienkiewicz H. Krzyżacy. Wrocław, Ossolineum Publishing House, 1990, ss. III-CVIII. Burkot S. Kraszewski. Studia historycznoliterackie. Warsaw, Ludowa Spółdzielnia Wydawnicza, 1988, 343 s.

Cubitt G. History of Memory. Debating New Approaches to History. London, New York, Oxford, New Delhi, Sydney, Bloomsbury Academic, 2019. P. 129-143.

Danek W. Powieści historyczne J. I. Kraszewskiego. Warsaw, Ludowa Spółdzielnia Wydawnicza Publ., 1966, $267 \mathrm{~s}$.

Ferro M. Resentyment w historii. Warsaw, Czytelnik Publ., 2013, 209 s.

Filler W. "Oto jest olbrzymów dzieło". Grunwald w polskiej literaturze i sztuce. Toruń, Adam Marszałek Publ., 2005, 152 s.

Gorskii I. K. Pol'skii istoricheskii roman i problema istorizma. Moscow, AN SSSR Press, 1963, 262 p.

Gudavičius E. Między kultem a rzeczywistością: rozważania o postrzeganiu Witolda Wielkiego w historiografii i społeczeństwie litewskim. Tematy polsko-litewskie. Historia - literatura - edukacja. Olsztyn, Wspólnota kulturowa Borussia Publ., 1999, ss. 54-66.

Hofman I. Krzyżacy 1410 J. I. Kraszewskiego a Krzyżacy H. Sienkiewicza. W stulecie Krzyżaków Henryka Sienkiewicza. Kielce, Kieleckie Towarzystwo Naukowe Publ., 2000, ss. 283-296.

Jarowiecki J. Powieści historyczne Ignacego Kraszewskiego (geneza i klasyfikacja). Rocznik Naukowo-Dydaktyczny Studium Terenowego Krakowskiej WSP w Rzeszowie. Nauki Humanistyczne, 1961, nr 1, ss. 143-177.

Julkowska V. Historia dla wyobraźni. Recepcja i interpretacja pisarstwa historycznego Karola Szajnochy. Poznań, Wydawnictwo Poznańskie, 2010, 407 s.

Karkut D. Wizerunki Władysława Jagiełły w literaturze i malarstwie. Zeszyty Naukowe Uniwersytetu Rzeszowskiego. Seria filologiczna, 2014, nr 86, ss. 69-78.

Kąkolewski I. Krzyżacy. Przeklęci i bohaterowie. Wyobrażenia przeszłości. Polsko-niemieckie miejsca pamięci. Warsaw, Scholar Publishing House, 2017, ss.73-96.

Kopczewski J.S., Siuchniński M. Grunwald. 550 lat chwały. Warsaw, Państwowe Zakłady Wydawnictw Szkolnych Publ., 1961, 289 s.

Kosman M. Henryka Sienkiewicza wizja Polski wspaniałej. Studia i szkice. Poznań, Adam Mickiewicz University Press, 1999, $244 \mathrm{~s}$.

Kosman M. Krzyżacy w historii i legendzie wieków. W 600 rocznice grunwaldzkiej wiktorii. Toruń, Wydawnictwo Naukowe Grado Publ., 2010, 250 s.

Kosmanowa B. Kraszewski mniej znany. Studia i szkice. Bydgoszcz, Wydawnictwo Uczelniane Wyższej Szkoły Pedagogicznej w Bydgoszczy Publ., 1998, 219 s.

Krawczyk J. Matejko i Historia. Warsaw, Instytut Sztuki Polskiej Akademii Nauk Publ., 1990, 226 s.

Krzyżaniakowa J., Ochmański J. Władysław II Jagiełło. Wrocław, Ossolineum Publishing House, 1990, 362 s.

Krzyżanowski J. Pokłosie Sienkiewiczowskie. Szkice literackie. Warsaw, Państwowy Instytut Wydawniczy Publ., 1973, 751 s.

Krzyżanowski J. Twórczość Henryka Sienkiewicza. Warsaw, Państwowy Instytut Wydawniczy Publ., 1973, $422 \mathrm{~s}$.

Kuczyński S. M. Jadwiga i Jagiełło Karola Szajnochy na tle jego życia i twórczości naukowej. Jadwiga i Jagiełło 1374-1413. Opowiadanie historyczne. T. 1-2. Warsaw, Państwowy Instytut Wydawniczy Publ., 1974, ss. $5-75$.

Kwiatkowski P. M. Jaką historią interesują się Polacy? Pytanie o kształt pamięci zbiorowej i jej przemiany po 1989 roku. Historia Polski od-nowa. Nowe narracje historii i muzealne reprezentacje przeszłości. Warsaw, Muzeum Historii Polski Publ., 2014, ss. 119-158.

Ludorowski L. Wizjoner przeszłości. Powieści historyczne Henryka Sienkiewicza. Lublin, Maria CurieSkłodowska University Press, 1999, 376 s.

Okoń W. Sztuka i narracja. O narracji wizualnej w malarstwie polskim II połowy XIX wieku. Wrocław, Wrocław University Press, 1988, 136 s.

Olszański K. Wojciech Kossak. Wrocław, Ossolineum Publishing House, 1982, 208 s. 
Opacka A. Litewska epopeja J. I. Kraszewskiego. Szkice o "Anafielas". Katowice, Uniwersytet Śląski University Press, 1988, $127 \mathrm{~s}$.

Poprzęcka M. Grunwald and Grunwald. Jan Matejko's Battle of Grunwald. New Approaches. Warsaw, The National Museum in Warsaw Publ., 2010, pp. 29-39.

Porębski M. Czy Matejko był malarzem? Wokół Matejki. Materiały z konferencji Matejko a malarstwo środkowoeuropejskie zorganizowanej w stulecie śmierci artysty. Cracow, Międzynarodowe Centrum Kultury Publ., 1994, ss. 19-24.

Prokofiewa D. A. Z historii publikacji utworów J. I. Kraszewskiego przez prasę rosyjską w latach 1830-1850. Chronologia i tło społeczno literackie. Józef Ignacy Kraszewski. Twórczość i recepcja. Lublin, Maria Curie-Skłodowska University Press, 1995, ss. 333-340.

Skowronek B. Film Krzyżacy Aleksandra Forda. W uścisku rozmaitych ideologii. Res Gestae. Czasopismo Historyczne, 2011, t. 11, ss. 186-194.

Słoczyński H. M. Matejko. Wrocław, Wydawnictwo Dolnośląskie Publ., 2000, 290 s.

Szulska I. Litwa Józefa Ignacego Kraszewskiego. Warsaw, Wydział Polonistyki Uniwersytetu Warszawskiego Publ., 2011, 513 s.

Świątek A. "Lach serdeczny". Jan Matejko a Rusini. Cracow, Jagiellonian University Press, 2013, 211 p.

Tomkiewicz R. Film Krzyżacy Aleksandra Forda. Komunikaty Mazursko-Warmińskie 2010, nr 2, ss. 169-183.

Traba R. Historia - przestrzeń dialogu. Warsaw, Instytut Studiów Politycznych Polskiej Akademii Nauk Publ., 2006, 274 s.

Traba R. Próby państwowej monopolizacji pamięci: Tannenberg 1927 (-1935) - Grunwald 1960. Polska Europa - Niemcy. Ksiega jubileuszowa z okazji siedemdziesiątej rocznicy urodzin Profesora Jerzego Holzera. Warsaw, Rytm Publ., 2000, ss. 485-501.

Treiderowa A. Obchody grunwaldzkie w Krakowie. Cracow, Towarzystwo Miłośników Historii i Zabytków Krakowa Publ., 1961, 47 s.

Urbańczyk A. Pomnik grunwaldzki w Krakowie. Cracow, Wydawnictwo Literackie Publ., 1974, 153 s.

Żabski T. Sienkiewicz. Wrocław, Wydawnictwo Dolnośląskie Publ., 1998, 320 s.

Статья поступила в редакцию 16 ноября 2020 г.

Рекомендована в печать 25 мая 2021 г.

Received: November 16, 2020

Accepted: May 25, 2021 